\title{
Potential Impact of Renewable Energy on the Sustainable Development of Russian Arctic Territories
}

\author{
Viktoriia Brazovskaia *(D), Svetlana Gutman (D) and Andrey Zaytsev (D) \\ Institute of Industrial Management, Economics and Trade, Peter the Great St. Petersburg Polytechnic University, \\ 195251 St. Petersburg, Russia; sgutman@spbstu.ru (S.G.); zajtsev.aa@spbstu.ru (A.Z.) \\ * Correspondence: viktoria.brazovskaya@yandex.ru or baeva.vv@edu.spbstu.ru
}

Citation: Brazovskaia, V.; Gutman, S.; Zaytsev, A. Potential Impact of Renewable Energy on the Sustainable Development of Russian Arctic Territories. Energies 2021, 14, 3691. https://doi.org/10.3390/en14123691

Academic Editor: Valentina Colla

Received: 17 May 2021

Accepted: 15 June 2021

Published: 21 June 2021

Publisher's Note: MDPI stays neutral with regard to jurisdictional claims in published maps and institutional affiliations.

Copyright: (c) 2021 by the authors. Licensee MDPI, Basel, Switzerland. This article is an open access article distributed under the terms and conditions of the Creative Commons Attribution (CC BY) license (https:// creativecommons.org/licenses/by/ $4.0 /)$.

\begin{abstract}
In recent decades, there has been a positive trend in world politics in the field of promoting territories' sustainable development. At the same time, one of the most relevant areas is to promote the transition to renewable energy sources (RES), which correspond to one of the UN's goals-Sustainable Development Goal 7 (SDG 7) “Ensuring universal access to affordable, reliable, sustainable and modern energy sources for all". This article is devoted to the study of the renewable energy sources' impact on the sustainable development of the Russian Arctic zone. The authors chose the level of carbon dioxide $\left(\mathrm{CO}_{2}\right)$ emissions as an indicator reflecting the impact of RES on sustainable development, since this factor is one of the main factors for assessing trends in the activities of countries aimed at achieving progress on most of the Sustainable Development Goals of territories. The hypothesis of the relationship between the use of renewable energy sources and the achievement of progress on the Sustainable Development Goals, one of the indicators of which is the level of $\mathrm{CO}_{2}$ emissions, was tested and confirmed. An econometric analysis of panel data for 15 countries that are actively implementing the concept of sustainable development, including decarbonizing policies, was carried out, where the resulting indicator for achieving progress on the SDG was the amount of $\mathrm{CO}_{2}$ emissions. The factors influencing the resulting variable were indicators selected based on a review of existing models, as well as indicators of the Sustainable Development Goals' achievement. Using an econometric analysis of interdependence, the indicators of progress towards the Sustainable Development Goals that are more likely to have an impact on the level of $\mathrm{CO}_{2}$ emissions were identified. These are electricity consumption, the share of renewable energy sources in the energy balance, the average per capita income of the population, and carbon intensity. Based on the results obtained, it can be concluded that renewable energy sources are a factor contributing to the achievement of progress on the Sustainable Development Goals. The results obtained are also applicable to the Arctic region, since all countries that have territories in the Arctic zone adhere to the policy of decarbonization and try to reduce the use of fossil fuels.
\end{abstract}

Keywords: sustainable development; sustainable investment; climate change; renewable energy; renewable energy sources; emissions

\section{Introduction}

At the present stage of development, due to the rapid progress of science and technology, the world community has faced a number of global problems. Global problems include climate change, ecosystem degradation, land and sea pollution, poverty and misery, lack of access to water and food for some of the inhabitants of our planet, etc. The escalation of global problems has led to a public awareness of the critical nature of the situation. People have begun to understand that ignoring changes in the usual patterns of production and consumption can lead to disastrous consequences. As such, the idea of switching to a new model of economic development—sustainable development—was born.

Recently, the issues of sustainable development have begun to attract wide attention of the population and governments of many countries around the world. More than a 
hundred countries at the state level make decisions that meet the concept of sustainable development, and develop and implement relevant programs and projects at different levels (national, regional, etc.). Countries pay special attention to the problem of global climate change in their programs. This is confirmed by the international treaty on climate change- the Paris Agreement, which was adopted by the countries at the 21st session of the Conference of the Parties to the UN Framework Convention on Climate Change in December 2015. The Paris Agreement aims to keep the global average temperature from rising and reduce the carbon dioxide $\left(\mathrm{CO}_{2}\right)$ content in the atmosphere. According to the agreement, countries report on planned measures to reduce greenhouse gas emissions (GHG), as well as on planned actions for sustainable development in order to adapt to a changing climate, in their nationally determined contributions [1]. Carbon dioxide $\left(\mathrm{CO}_{2}\right)$ is considered the most important greenhouse gas of anthropogenic origin, because it occurs naturally in the carbon cycle, but it is man who has increased its concentration in the atmosphere by $47 \%$ since the Industrial Revolution. In September 2019, Russia announced the adoption of the Paris Climate Agreement. This agreement is a clear signal of the government's readiness to implement the 2030 Agenda for Sustainable Development. The implementation of the Paris Agreement is critical to achieving the Sustainable Development Goals. The Agreement provides a roadmap for measures that will reduce emissions and strengthen resilience to climate change.

Climate change in the Arctic zone has a significant impact on the development of societies and economies around the world, as climate change in the Arctic is moving at a faster pace. As scientists have proved in their study on the state of the Arctic during the last interglacial period [2], it is necessary to work more actively on the implementation of new measures to reduce harmful emissions. This will slow down the warming of the Arctic and give humanity time to prepare for drastic climate changes after the disappearance of the polar ice cap.

In view of the climate changes on the planet, the assessment of the potential for the cost-effective use of renewable energy sources (RES) and measures to encourage their further spread is considered as a priority policy of adaptation of the Arctic region of Russia to climate change [3]. The full-scale development of the mineral and energy resources of the richest Arctic continental shelf is also beginning, which is due to the depletion of mineral reserves of the continental part of the Earth and directly affects the structure of the world's energy supply. The involvement in the industrial turnover of RES in the Arctic using wind, geothermal, ocean circulation, wave, and planetary gravity (tides) energy in conjunction with the development of deep-water areas of the Arctic Ocean floor generates a wide range of technological innovations used in various spheres of life [4]. In modern research, renewable energy is considered as an incentive for sustainable economic growth, which has great potential for development.

To date, in the Russian Federation, RES make up only a small part of the total energy production, but in the last few years there has been a tendency to increase the production of renewable energy, which is especially important for remote and sparsely populated areas of the Arctic zone of the Russian Federation.

One of the main points of the concept of sustainable energy is to increase the share of renewable energy in the global energy balance to $30 \%$ and reduce $\mathrm{CO} 2$ emissions by 75-90\% compared to 1990 [5].

The relevance of the research topic, its theoretical and practical significance determined the purpose and objectives of the study - to identify the impact of RES on the sustainable development of territorial socio-economic systems in the context of achieving the Sustainable Development Goals. Based on the analysis of panel data, testing the hypothesis that an increase in the share of renewable sources in the country's energy balance contributes to progress in achieving the Sustainable Development Goals, one of the indicators is the reduction in the amount of $\mathrm{CO} 2$ emissions into the atmosphere. 


\section{Literature Review}

At the moment, the reverse side of the intense activity of the Russian Federation in the Arctic zone is its extensive pollution - the territory of the Arctic coast, which belongs to the Russian Federation, is considered one of the most polluted territories in the world [6]. "According to approximate estimates, the coastal zones of the Arctic Ocean contain up to four million tons of construction and industrial waste, which, moreover, is considered highly toxic" [7].

The basis of the energy of the Arctic region is fossil fuel imported from other regions. Due to the catastrophic pollution of the Arctic territories, it is necessary to take into account the environmental aspect: for example, the use of fuel oil and diesel in the Arctic is unacceptable in the light of the current focus on preserving the natural resources of the Arctic.

In addition, the organization of all logistics processes is further complicated by the lack of a developed transport infrastructure and the harsh climate of the Arctic, so the possibilities of transporting fuel to this region are significantly limited. "The difficulties of transporting fuel entail high transport costs, which affect the final cost of energy produced. To reduce such costs, it is necessary to radically change the approach to energy supply in the region" [8]. Therefore, the choice fell on the use of renewable energy, as the most promising local use in terms of reducing the cost of transporting fuel to the Russian Arctic regions [9].

The authors in their research [10] also consider the problem of severe deterioration of the infrastructure of the Arctic zone, especially energy. The degree of depreciation of fixed assets of the Arctic generating energy complex exceeds $60 \%$. With the stated growth rate of electricity consumption almost two times by 2020 compared to 2007 [11], given that the average operating cycle of the power plant is $20-30$ years, by 2020 the generating capacity of the Arctic region should be completely updated. Authors in the article [12] describe the seasonal unevenness of energy consumption in remote settlements. To ensure their power supply, it is necessary to introduce additional capacities, since the deviation of real loads from the indicators used in the calculations of energy balances for the summer regime day can be $40-50 \%$.

In the context of modern environmental and climatic challenges, the use of renewable energy resources can become an effective solution to many local energy problems, such as using solid-state lighting instead of traditional lighting technologies [13-15].

Successful examples of RES implementation in the Arctic energy sector are increasingly appearing: a combined solar-wind-diesel installation, photovoltaic converters [16] and three small solar-wind installations in various settlements of the Murmansk Region [17].

The possibilities of using solar and wind energy in the Arctic zone are considered in this research [18]. The article indicates that in areas with average wind speeds of $6-7 \mathrm{~m} / \mathrm{s}$ or more, wind power can develop. There are favorable conditions for the development of solar energy. The average annual energy input from direct solar radiation in the Arctic varies from 2 to $5 \mathrm{kWh} /\left(\mathrm{m}^{2} \times\right.$ day $)$. In Kamchatka and Chukotka, there are conditions for the development of geothermal energy, and in the southern part of the western regions for the development of bioenergy based on the use of wood waste and low-grade wood. In the longer term, the development of tidal energy may be of interest.

The authors of study [19] investigated the potential of RES use in the Arctic. One of the most promising areas of renewable energy in the Arctic region is the use of wind energy. According to the research of Bezrukikh P. P. [20], the Russian coast of the Arctic and Pacific Oceans has a significant gross potential of wind resources. The results of the article [21] discuss some aspects and features of the development of wind energy in northern and remote areas. In some areas of the Arctic coast and remote areas, wind speed is quite important; on the one hand, this is considered a very favorable environment for the cost-effective use of wind energy. On the other hand, exceeding the wind speed of certain limits can lead to significant loads on the components and parts of wind turbines, which will lead to the destruction of the device as a whole. 
Solar resources, according to the atlases of solar potential, cannot be used as the main source of energy. The Arctic territories are characterized by short-term sunshine (less than $1700 \mathrm{~h}$ /year). However, solar-powered plants can be used as small-scale generation facilities for small objects.

In Russia, the situation is more complicated than, for example, in Northern Norway, where almost all electricity is supplied by RES. The territory of the Arctic zone of the Russian Federation is much larger and more diverse. Moreover, In Russia, the distances between scarcely populated settlements are much longer than in the Norway. In the northernmost latitudes, there is a potential for wind energy, and in a number of eastern Arctic regions (for example, in Yakutia) the solar potential is high. Therefore, as the authors say in the article [22], it is necessary to study the natural and economic opportunities for the development of RES in each individual case-even at the local level-and make decisions on development based on considerations of payback and efficiency.

Yu. A. Nazarova et al. in their article [23] consider more innovative options for using RES in the Arctic zone. The first option involves the use of a wind-diesel installation with a storage system. The second option is a wind power plant with a system for storing and using energy in the form of hydrogen bound in a liquid organic carrier.

For the implementation of renewable energy projects in the Arctic region, Potravny I. M. et al. suggest using public-private partnership as one of the main tools for attracting investment resources in infrastructure projects [24].

In most regions of the Russian Arctic, a relatively small number of projects in the field of RES have been implemented, despite their significant potential. Therefore, for the implementation of projects for the RES construction and operation in the Arctic zone of the country, it is advisable to use the mechanism of public-private partnership, which involves a legally formalized agreement between public authorities and business on the construction and operation of these facilities, mutually beneficial cooperation between public authorities and business in the process of implementing projects for the construction and use of renewable energy facilities in the Russian Arctic.

As the result of the article [25], the authors propose to use RES in the Arctic zone of Canada as a priority source of energy for remote areas. Other authors propose to use RES for heat production and storage, which, as a result, will lead to a decrease in the use of fossil fuels [26]. Das I. et al. do not consider a complete transition to RES, but rather the integration of RES into diesel microgrids in the Canadian Arctic [27].

RES also play an important role in providing for the Norwegian Arctic territories. Norway is one of the leading countries in the development of RES in the world. Since the 1870s, hydroelectric resources have provided mainland Norway with a clean and stable energy supply, and now their capacity provides $99 \%$ of all electricity produced in Norway, including in the Arctic (mainly hydroelectric power is used). For example, in 2013, this share was $96 \%$, i.e., Norway produced a total of 134 billion $\mathrm{kWh}$, of which 129 were generated by hydroelectric power plants. In addition, the wave energies caused by wind, sea, and swell along the Norwegian coast are considered a key source of energy [28].

China is a world leader in the use of renewable energy in its energy mix [29]. That is the reason why the example [30] of China's cooperation with Western countries (cooperation with Northern Europe countries such as Iceland, Sweden, Norway, Finland and Denmark, and North American countries such as Canada and the USA) in the context of sustainable use of natural resources in the Arctic region is very interesting. The authors argue that the sustainable development of the region is impossible without the transition to energy supply based on RES.

We can consider an interesting case in China, where scientists are implementing their developments in not only their own country, but also exploring the possibilities of renewable energy for remote areas. For example, scientists Jung, W. et al. argue that RES and energy storage systems are the future for remote territories and energy-isolated islands [31]. As a result, it was found that the optimal capacity of onshore wind turbines, offshore wind turbines, solar photovoltaic panels and lithium-ion batteries is $4695 \mathrm{MW}$, 
$3592 \mathrm{MW}, 182 \mathrm{MW}$ and $25.5 \mathrm{GWh}$, respectively. The required area corresponding to the optimal capacity was estimated as $219 \mathrm{~km}^{2}, 165 \mathrm{~km}^{2}, 0.917 \mathrm{~km}^{2}$ and $0.036 \mathrm{~km}^{2}$.

It is interesting to note that some scientists consider RES for not only electricity and heat supply of the Arctic territories, but also as a basis for infrastructure. RES is considered for working with some types of engines, which will reduce emissions of harmful substances into the environment, which is especially important in the Arctic region [32]. Scientists propose to use RES to provide a reliable, self-sufficient, universal environmental monitoring station S3ME2 with a variety of sensors that can operate in extreme conditions [33]. The issues of energy efficiency and renewable energy technologies (RES) in the development of the concept of transport hubs for the conditions of the Far North also widely discussed [34].

Summing up, we can conclude that the use of renewable energy in the Arctic is relevant not only as a source of electricity, but also as a basis for ensuring the functioning of infrastructure in this region and sustainable development.

As mentioned earlier, one of the main tasks of the development of the Arctic region is to protect the vulnerable nature of the North, reduce the anthropogenic load on the environment during the development of territories, and preserve the traditional culture and way of life of indigenous peoples. The solution of the set tasks relates to the sustainable development of energy in remote areas, reliable supply of production and population with energy, taking into account environmental requirements in the context of preventing climate change.

Some of these problems need to be addressed in detail [35]. Table 1 presents possible ways to reduce human anthropogenic impact.

Table 1. Main global problems of human anthropogenic impact.

\begin{tabular}{ccc}
\hline Type of Human Anthropogenic Impact & Ways to Reduce Harmful Impact & $\begin{array}{c}\text { Related Sustainable Development } \\
\text { Goals }\end{array}$ \\
\hline Emissions and discharges & $\begin{array}{c}\text { Limitation of maximum permissible } \\
\text { emissions and discharges, disposal of } \\
\text { production and consumption waste }\end{array}$ & SDG 6,7,11,12,13,14,15 \\
\hline Depletion of natural resources & $\begin{array}{c}\text { Establishment of permissible limits for the } \\
\text { use of natural resources of the territory }\end{array}$ & SDG 6,7,9,11,12,13,14,15,16,17 \\
\hline $\begin{array}{c}\text { Rapid development of mining and } \\
\text { industrial production enterprises }\end{array}$ & $\begin{array}{c}\text { Justification of the maximum level of } \\
\text { development of enterprises, introduction of } \\
\text { an environmentally safe structure of } \\
\text { enterprises, territorial restrictions of } \\
\text { economic activity, up to a complete ban }\end{array}$ & SDG 6,9,11,12,13,14,15,17 \\
\hline
\end{tabular}

In many countries that have Arctic territories in their composition, a ban on the use of diesel fuel has already appeared. For example, the territories of Alaska completely abandoned its use, replacing it with RES. First, the transportation of diesel fuel to remote areas increases the cost of electricity quite significantly. Secondly, diesel plants emit a large amount of pollutants into the atmosphere, nitrogen and carbon oxides, which is contrary to the Paris Agreement of 2015. This agreement, within the bounds of the UN Framework Convention on Climate Change, regulates measures to reduce the content of $\mathrm{CO} 2$ in the atmosphere, and also calls for reducing the consumption of fossil fuels [36].

The fight against human anthropogenic impact and its consequences should be carried out in a comprehensive manner. These activities should include improving the technology and extraction of natural resources, as well as their economic use. Production should be waste-free, and it is imperative to introduce closed production cycles, as well as deep cleaning and technologies for the use of production waste and reuse materials after the products are out of use. To preserve the ecosystem, it is necessary to protect and breed rare species of plants and animals, expand and increase the number of nature reserves, zones of reference ecosystems, and unique natural complexes. All these actions should be accompanied by global monitoring of the most important characteristics of environment health, 
broad environmental education of the population, as well as international cooperation of countries in the field of environmental protection [37].

For the energy sector, the key task is the application of energy-saving technologies and the development and use of new environmentally friendly energy sources.

It is worth noting that at this stage, RES in Russia is at the stage of its origin, and it is necessary to work out the regulation of this industry in more detail. Therefore, it is interesting to consider the legal aspects of countries that have succeeded in using RES in their energy balance; for example, Germany, where the Federal Government, with the support of all parties, proposed a policy of restructuring the energy sector, called Energiewende ("energy turn"). This policy involves the gradual abandonment of the use of hydrocarbons, the complete abandonment of the use of nuclear fuel and the transition to generation based on renewable sources. It is also worth noting that Germany has adopted a separate full-fledged law on renewable energy, Gesetz für den Ausbau erneuerbarer Energien (Erneuerbare-EnergienGesetz, EEG), and unlike in the Russian Federation, RES is only part of the law on electricity. The purpose of this law is to promote climate protection and environmental protection, as well as the conservation of fossil energy sources. In addition, Germany is gradually withdrawing from the energy balance of nuclear power plants, which only confirms the active actions of the country in this direction, and not only their existence on paper. The German energy revolution is not only an ecological restructuring, but also an economic and political one. It is based on ensuring energy independence from other countries and energy security, supporting innovation, and creating new jobs. In addition, the most important factor in this transition is the interest of many parties: businesses and most of the residents, who are willing to overpay, but recieve clean energy. According to the law on renewable sources, the energy produced by RES in Germany has a preferential right of access to the network. At the same time, grid companies are required to expand their networks in accordance with technical standards in order to prioritize the reception, transmission and distribution of electricity generated on the basis of RES. The state, for its part, supports and subsidizes renewable energy. For example, for generating companies, a guarantee of a fixed compensation per kilowatt-hour of electricity generated on the basis of renewable energy is provided for a period of 20 years from the date of commissioning of the plant.

As mentioned above, one of the key reasons for the transition to renewable energy is the desire of the world community to reduce harmful emissions. Corinne Le Quéré et al. [38] identify states that experience a significant reduction in $\mathrm{CO}_{2}$ emissions from 2005 to 2015. When they analyzed the reasons, it turned out that the reduction in emissions is mainly due to the replacement of fossil fuels with renewable sources and increased energy efficiency. Further, all countries are actively adhering to climate and energy policies-it is in these countries that emissions have decreased the most. In total, the transition to clean energy has helped reduce emissions in 18 developed countries, including the UK, the US, Germany and France. Together, they produce $28 \%$ of the GHG released into the atmosphere.

In the work of S. Tishkov et al. [39], the authors consider the question of the role of RES in reducing $\mathrm{CO}_{2}$ emissions. The authors put forward a hypothesis: an increase in the share of RES leads to a reduction in $\mathrm{CO}_{2}$ emissions. One model was built according to the data of the European Union countries from 1990 to 2018, and the other-for Belarus, Russia and Kazakhstan. The authors decide to separate the country data, because the share of renewable energy in the European Union has been growing much faster in recent years.

According to the results, for European countries, the consumption of fossil fuel energy contributes to $\mathrm{CO}_{2}$ emissions, and an increase in the share of renewable energy contributes to reducing emissions. For Belarus, Russia, and Kazakhstan, increased use of fossil fuels, as well as GDP per capita, leads to increased emissions. For European countries, the FuelCons (fuel consumption) coefficient assumes that a 1\% increase in energy consumption from fossil fuels will result in a $1.5 \%$ increase in per capita $\mathrm{CO}_{2}$ emissions. 
The authors Marin G. et al. investigate the relationship between $\mathrm{CO}_{2}$ emissions and economic growth at the level of individual sectors of the Italian economy in 1990-2007 [40]. As a result, the authors conclude that there is a direct relationship between the increase in production and emissions into the atmosphere. In addition, it is interesting that the increase in the share of the service sector is accompanied by a more pronounced reduction in the environmental burden than the impact of the growth of manufacturing production.

It is worth noting that the level of $\mathrm{CO}_{2}$ emissions is the most commonly used indicator of emissions into the atmosphere, as well as an indicator of environmental pollution. It is also the main indicator for the international community's assessment of the actions of countries in addressing the problem of global climate change. In this study, we will consider which factors have the greatest impact on $\mathrm{CO}_{2}$ emissions.

\section{Materials and Methods}

The methodological basis for the study was determined by the indicators selected based on the review of scientific papers on this topic. In work of Kudryavtseva O. V. et al., the study on the relationship between environmental pollution and the economic growth of countries is conducted [41]. At the same time, the key factors are the CPI, GDP, and foreign investment. Other works shows a cyclical relationship between GDP growth, $\mathrm{CO}_{2}$ emissions, natural disasters, and economic problems [42].

In the work of S. Tishkov et al. [39], the authors consider the question of the role of RES in reducing $\mathrm{CO}_{2}$ emissions. The authors put forward a hypothesis: an increase in the share of RES leads to a reduction in $\mathrm{CO}_{2}$ emissions. The authors also use indicators such as electricity and fossil fuel consumption in their study.

Scientists consider the influence of the level of urbanization of countries, the level of well-being and energy consumption on the level of $\mathrm{CO}_{2}$ emissions [43]. This paper empirically examines the impact of urbanization on energy consumption and $\mathrm{CO}_{2}$ emissions, taking into account different stages of development. Using the stochastic regression model STIRPAT and a balanced panel dataset of 99 countries for the period from 1975 to 2005, the results suggest that the impact of urbanization on energy consumption and emissions varies at different stages of development. Other authors in their research [44] also use the STIRPAT model, which, according to them, allows us to study the influence of various factors on the level of environmental pollution. For the analysis, the authors take data from 77 countries, using the following factors as government spending and household income. As a result, the authors conclude that government spending has little positive impact on $\mathrm{CO}_{2}$ emissions.

Especially for the China special aspects, scientists in their work [45] transformed the STIRPAT model (see formula (1)):

$$
\ln (I)=3.06 \ln (P)+0.13 \ln (A) 0.19 \ln (T)+0.54 \ln (\mathrm{UL})+1.1 \ln (\mathrm{ECS})-0.12 \ln (\mathrm{ES})-2.57
$$

where

- $\quad$ - I-the amount of CO2 emissions in China (ten thousand tons);

- $\quad P$-total population (ten thousand people);

- $\quad A$-China's GDP (ten thousand yuan);

- $\quad T$-carbon intensity (CO2 emissions per GDP: tons/ten thousand yuan);

- $\quad$ UL- the share of the urban population in the total population (\%);

- $\quad$ ECS - the structure of energy consumption (the share of coal consumption in energy consumption, \%);

- $\quad$ ES - the structure of the economy (the share of the output value of the second industry in GDP, \%).

To develop their own econometric model and test the stated hypothesis, the study includes data on countries from different parts of the world that have active policies to reduce $\mathrm{CO}_{2}$, as well as those that are implementing certain measures to reduce emissions 
at the stage of their development. The criteria for selecting countries are decarbonization policy, as well as the transition from traditional energy to RES.

In this study, the authors form a data panel for 15 countries for the period from 2007 to 2016. The peculiarity of panel data is that it contains statistical information about the same set of objects for a number of consecutive time periods. Therefore, if the authors consider regression analysis, when using this type of data, the volume of the sample under consideration increases, which provides greater efficiency in estimating the parameters of the regression model. Additionally, using the data panel, the authors compensate for many negative aspects of using only spatial or only temporal data, i.e., in this case, the authors can say that they have avoided the loss of information, which is associated in the first case with an underestimation of the dynamics of the development of objects, and in the second case-with the inability to take into account the heterogeneity of the objects themselves. Traditionally, panel data analysis is performed using different modeling approaches:

1. Regression on pooled data. The model parameters $(m+1)$ are estimated using OLS for all nt observations. The use of the method is justified if the existence of heterogeneous characteristics of the objects of observation or time points is not assumed. Otherwise, the OLS assumptions about balances are violated.

2. Fixed effects models. This model assumes the presence of individual unobservable effects for each of the studied spatial objects. Using this model, it becomes possible to control the bias of estimates caused by individual effects of objects.

3. Random effects models. Unlike fixed-effect models, it is assumed that differences between spatial features exist, but are random in nature.

At the first stage of the regression analysis, the factors that can influence the dependent variable are selected. In this study, the hypothesis assumes that there are significant causal relationships between the level of $\mathrm{CO}_{2}$ emissions and indicators that reflect the level of economic development of countries, as well as the share of RES in the country's energy balance. The authors choose the variable number of $\mathrm{CO}_{2}$ emissions per year as the dependent variable. In this paper, the authors also choose the level of $\mathrm{CO}_{2}$ emissions as a measure of environmental pollution. This indicator is reflected in the Kyoto Protocol of 1997, as well as in the Paris Climate Agreement of 2015. In this regard, in the future, the authors understand the level of pollution as the emission of $\mathrm{CO}_{2}$, as a substance that causes one of the global problems-global climate change.

The authors carry out regression analysis of the data in the software package for solving statistical problems Stata. For the selected indicators, the authors perform a correlation analysis at the first stage to assess the presence and direction of links. Then the authors construct various versions of the models, each of which is tested for compliance with the provisions of the Gauss-Markov theorem. As a result, the authors select the model with the best characteristics, which successfully passed all the tests.

To test our hypothesis that increasing the share of renewable sources in a country's energy balance helps to reduce the amount of harmful emissions into the atmosphere, the authors conduct a traditional econometric analysis using panel data.

The resulting variable is the amount of $\mathrm{CO}_{2}$ emissions in megatons per year. The factors influencing the resulting variable are indicators selected based on a review of existing models. The authors also add factors of interest to this study, such as the share of renewable energy in the country's energy mix. Using the econometric analysis of the interdependence, the authors identify those indicators that are more likely to have an impact on the level of $\mathrm{CO}_{2}$ emissions.

Table 2 shows the selected variables for the study. Based on them, the authors build a regression model, which will give us information about the relationship of the selected factors with $\mathrm{CO}_{2}$ emissions. 
Table 2. List of factors used.

\begin{tabular}{|c|c|c|c|c|}
\hline NO & Indicator & $\begin{array}{l}\text { Designation in } \\
\text { the Model }\end{array}$ & $\begin{array}{c}\text { Unit of } \\
\text { Measurement }\end{array}$ & Relevant Sustainable Development Subgoals \\
\hline 1. & $\begin{array}{l}\text { Amount (level) of } \\
\mathrm{CO}_{2} \text { emissions }\end{array}$ & $\mathrm{CO}_{2}$ & megatons & $\begin{array}{l}\text { 3.9 By 2030, significantly reduce the number of deaths and } \\
\text { diseases from hazardous chemicals, air, water and soil } \\
\text { pollution. } \\
\text { 7.3 By } 2030 \text {, double the global rate of energy efficiency } \\
\text { improvement. } \\
\text { 9.4.1 Reduce total } \mathrm{CO}_{2} \text { emissions per unit of value added. } \\
\text { 11.6 By 2030, reduce the negative impact of cities on the } \\
\text { environment per capita, including by focusing on air quality } \\
\text { and the disposal of municipal and other waste } \\
\text { 13.2.2 Reduce total gas emissions per year. }\end{array}$ \\
\hline
\end{tabular}

\begin{tabular}{|c|c|c|c|c|}
\hline 2. & $\begin{array}{l}\text { The amount of } \\
\text { electricity } \\
\text { consumed per year }\end{array}$ & EL & TW/year & 7.1.1 Proportion of the population with access to electricity \\
\hline 3. & $\begin{array}{l}\text { Annual coal } \\
\text { consumption }\end{array}$ & COAL & megatons & $\begin{array}{l}\text { 7.1.2 Proportion of the population that primarily relies on } \\
\text { clean fuels and technologies } \\
12.2 \text { By } 2030 \text {, achieve sustainable management and efficient } \\
\text { use of natural resources. }\end{array}$ \\
\hline 4. & GDP per capita & VVP & $\begin{array}{c}\text { million US } \\
\text { dollars }\end{array}$ & $\begin{array}{l}\text { 8.1 Maintaining per capita economic growth in line with } \\
\text { national circumstances and, in particular, gross domestic } \\
\text { product growth of at least } 7 \text { per cent per year in the least } \\
\text { developed countries. } \\
\text { 17.1 Strengthening domestic resource mobilization, } \\
\text { including through international support to developing } \\
\text { countries, to improve domestic capacity to collect taxes and } \\
\text { other revenue }\end{array}$ \\
\hline 5. & $\begin{array}{l}\text { The share of } \\
\text { renewable energy } \\
\text { in the total energy } \\
\text { balance of the } \\
\text { country }\end{array}$ & RE & $\%$ & $\begin{array}{l}\text { 7.2.1 Share of renewable energy sources in total final energy } \\
\text { consumption } \\
\text { 12.a.1 Installed renewable energy capacity in developing } \\
\text { countries (in watts per capita) } \\
\text { 17.7 Promote the development, transfer, dissemination and } \\
\text { dissemination of environmentally sound technologies. }\end{array}$ \\
\hline 6. & $\begin{array}{l}\text { The share of the } \\
\text { urban population in } \\
\text { the total population }\end{array}$ & URB & $\%$ & $\begin{array}{l}\text { 9.1 Develop quality, reliable, sustainable and sustainable } \\
\text { infrastructure, including regional and cross-border } \\
\text { infrastructure, to support economic development and } \\
\text { human well-being, with a focus on affordable and equitable } \\
\text { access for all. } \\
\text { 11.1 By 2030, ensure access for all to adequate, safe and } \\
\text { affordable housing and basic services }\end{array}$ \\
\hline 7. & $\begin{array}{l}\text { Export of } \\
\text { technological } \\
\text { innovations }\end{array}$ & TEC2 & $\begin{array}{c}\text { million US } \\
\text { dollars }\end{array}$ & $\begin{array}{l}\text { 2.a Increase investment, including through enhanced } \\
\text { international cooperation, in rural infrastructure, } \\
\text { agricultural research and extension services, technology } \\
\text { development, and plant and animal genetic banks. } \\
\text { 7.a By 2030, expand international cooperation to facilitate } \\
\text { access to clean energy research and technology. } \\
\text { 17.7.1 Total funding for developing countries to promote the } \\
\text { development, transfer, dissemination and dissemination of } \\
\text { environmentally sound technologies. }\end{array}$ \\
\hline
\end{tabular}


Table 2. Cont.

\begin{tabular}{|c|c|c|c|c|}
\hline NO & Indicator & $\begin{array}{l}\text { Designation in } \\
\text { the Model }\end{array}$ & $\begin{array}{c}\text { Unit of } \\
\text { Measurement }\end{array}$ & Relevant Sustainable Development Subgoals \\
\hline 8. & $\begin{array}{l}\text { Per capita income } \\
\text { of the population }\end{array}$ & ERN & US dollars/year & $\begin{array}{l}\text { 1.2 By 2030, reduce by at least half the proportion of men, } \\
\text { women and children of all ages living in poverty in all its } \\
\text { dimensions. } \\
2.1 \text { By 2030, ensure access to safe, nutritious and sufficient } \\
\text { food for all people all year round. } \\
4.3 \text { By 2030, ensure equal access for all women and men to } \\
\text { affordable and high-quality technical, vocational and higher } \\
\text { education, including university education. } \\
8.8 \text { Protect labour rights and promote safe and secure } \\
\text { working conditions for all workers } \\
\text { 10.1.1 Growth rate of household expenditure or per capita } \\
\text { income among the poorest } 40 \text { per cent of the population and } \\
\text { the entire population. } \\
\text { 16.10 Ensure public access to information and protect } \\
\text { fundamental freedoms in accordance with national } \\
\text { legislation and international agreements. }\end{array}$ \\
\hline 9. & $\begin{array}{l}\text { The share of the } \\
\text { service sector in the } \\
\text { total GDP }\end{array}$ & SI & $\%$ & $\begin{array}{l}\text { 2.c Take measures to ensure the proper functioning of } \\
\text { markets for food products and their derivatives and promote } \\
\text { timely access to market information, including on food } \\
\text { reserves, to help limit extreme food price volatility. } \\
\text { 9.3.1 Increase the share of small enterprises in the total value } \\
\text { added of the industry }\end{array}$ \\
\hline 10. & Population density & POP & people $/ \mathrm{km} 2$ & $\begin{array}{l}\text { 2.a Increase investment, including through increased } \\
\text { international cooperation, in rural infrastructure, } \\
\text { agricultural research and extension services, technology } \\
\text { development, and plant and animal genetic banks to } \\
\text { enhance agricultural productive capacity } \\
\text { 11.3 By 2030, strengthen inclusive and sustainable } \\
\text { urbanization and capacity for collaborative, integrated and } \\
\text { sustainable human settlements planning and management in } \\
\text { all countries. }\end{array}$ \\
\hline 11. & $\begin{array}{c}\text { Carbon intensity } \\
\left(\mathrm{CO}_{2} \text { emissions per }\right. \\
\text { GDP })\end{array}$ & INT & $\begin{array}{l}\text { tons / ten } \\
\text { thousand US } \\
\text { dollars }\end{array}$ & $\begin{array}{l}\text { 6.3 By 2030, improve water quality by reducing pollution, } \\
\text { eliminating discharges and minimizing emissions of } \\
\text { hazardous chemicals and materials, halving the proportion } \\
\text { of untreated wastewater, and significantly increasing } \\
\text { recycling and safe reuse worldwide. } \\
7.3 \text { By 2030, double the global rate of energy efficiency } \\
\text { improvement } \\
8.4 \text { Progressively improve global resource efficiency in } \\
\text { production and consumption by 2030, and strive to separate } \\
\text { economic growth from environmental degradation. } \\
\text { 14.1 By 2025, prevent and significantly reduce marine } \\
\text { pollution of all types, in particular from land-based activities, } \\
\text { including pollution of marine debris and nutrients }\end{array}$ \\
\hline
\end{tabular}

To collect data on the described indicators (factors), the authors use the following databases: The World Bank, as well as data from the OECD, Eurostat, IMF, Rosstat, data from the Global Carbon Atlas website and other sources.

First of all, it is necessary to build a model of the relationship between the amount of $\mathrm{CO}_{2}$ emissions and socio-economic factors. To do this, the authors perform a regression analysis (Table 3) based on the original data. 
Table 3. List of factors used.

\begin{tabular}{ccc}
\hline The Resulting Indicator & Variables/Model Parameters & $\begin{array}{c}p>|\mathbf{t}| \\
(\boldsymbol{p} \text {-Value }) / \text { Parameter Value }\end{array}$ \\
\hline CO2 & EL & 0.000 \\
& VVP & 0.004 \\
RE & 0.166 \\
URB & 0.048 \\
ERN & 0.005 \\
SI & 0.001 \\
POP & 0.383 \\
INT & 0.000 \\
COAL & 0.000 \\
TEC2 & 0.008 \\
Constanta & 0.228 \\
\hline Model Parameters & Parameter value \\
& $R^{2}$ & 146 \\
$R^{2} a d j$ & 0.9971 \\
RMSE & 0.9969 \\
& & $1.4 \times 10^{5}$ \\
\hline
\end{tabular}

The resulting model is of sufficiently high quality, because in general it is significant (according to Fischer's F-criterion). The coefficient of determination is 0.9971 , and the adjusted coefficient of determination is 0.9969, which means that the variance of the selected indicators explains most of the $\mathrm{CO}_{2}$ variance. However, it should be noted that the model contains a large number of indicators, two of which may not be significant (URB, POP), as well as a constant.

Next, the authors need to check the linearity of the relationship between the selected factor variables and the dependent variable. Choosing the right functional shape greatly affects the quality of the model.

The result is shown in Figure 1.
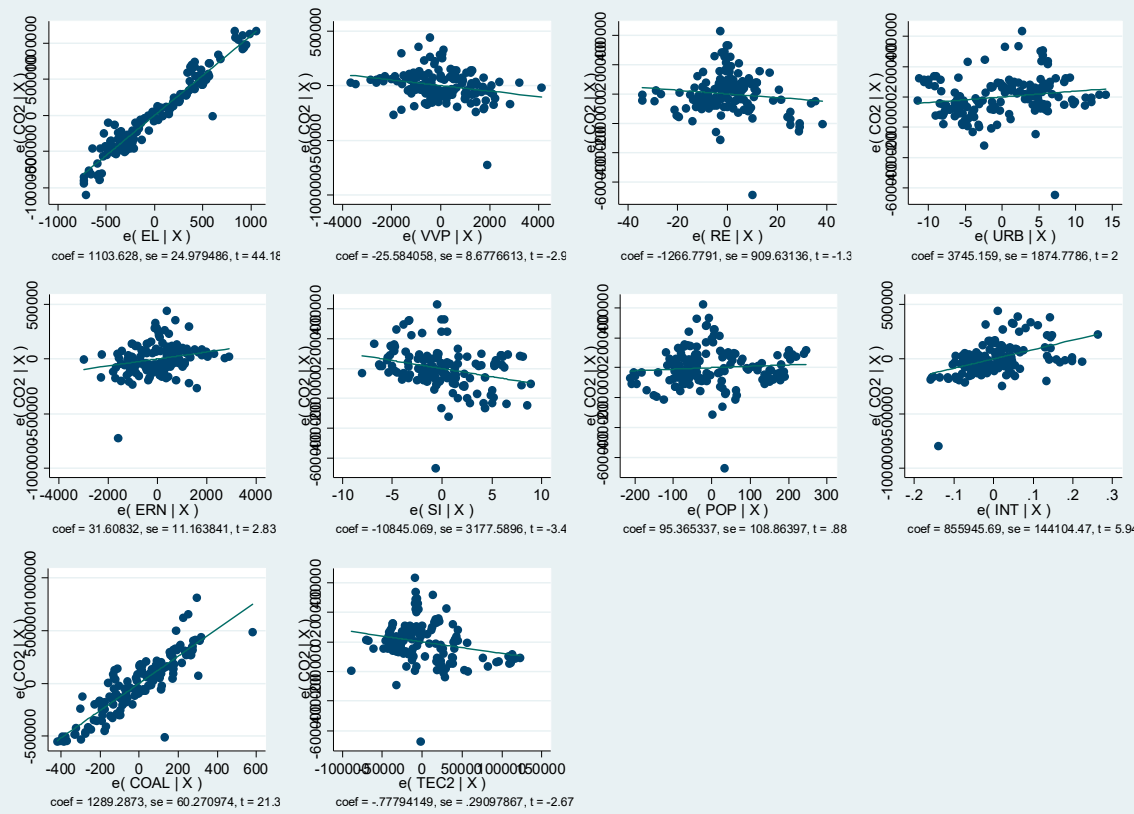

(a) $=12892873, s 9=60270974, t=213$

coef $=-77794149, \mathrm{se}=29097867, \mathrm{t}=-2.67$

Figure 1. Test of the linearity of the relationship between the dependent variable and the factors. 
The linearity test (Figure 1) shows the presence of linear relationships between the variables and the result. The linear dependence of the resulting variable "amount of $\mathrm{CO}_{2}$ emissions" on the factor variables is found in most of the considered studies on this problem [41-46].

The next step is to analyze this model for multicollinearity of factors. The vif test showed significant collinearity between some variables. Since each factor reflects a particular sustainable development goal, the presence of multicollinearity proves the relationship between all the Sustainable Development Goals. The analysis of the correlation matrix shows significant links between electricity consumption, the share of RES, the average per capita income of the population and $\mathrm{CO}_{2}$ emissions. In addition, some of the coefficients for variables are insignificant. In this regard, the authors adjust the specification of the model. By performing several iterations, the authors obtain the most favorable econometric model. In the final model, the following variables remain: the level of $\mathrm{CO}_{2}$ emissions, the amount of electricity consumed per year, the share of renewable energy in the total energy balance of the country, carbon intensity $\left(\mathrm{CO}_{2}\right.$ emissions per GDP), the average per capita income of the population, the share of the service sector in the total GDP. The results of the regression analysis of the final model, its analysis for multicollinearity of factors and checking the linear relationship between the variables and the resulting variable are shown in Tables 4 and 5 and Figure 2.

Table 4. Final regression model.

\begin{tabular}{cccc}
\hline The Resulting Indicator & $\begin{array}{c}\text { Variables and Model } \\
\text { Parameters }\end{array}$ & $\begin{array}{c}\boldsymbol{p}>\mathbf{| t |} \\
(\boldsymbol{p} \text {-Value })\end{array}$ & Coef. \\
\hline $\mathrm{CO}_{2}$ & $\operatorname{lnEL}$ & 0.000 & 0.8718709 \\
& $\mathrm{RE}$ & 0.000 & -0.0138309 \\
& sqrtERN & 0.000 & -0.0038339 \\
& Constanta & 0.000 & 0.3654792 \\
& Model parameters & Parameter value & 9.255415 \\
& $N$ & 148 & 0.000 \\
$R^{2}$ & 0.9414 & 0.9397 \\
$R^{2} a d j$ & 0.39495 \\
\hline
\end{tabular}

Table 5. Identification of multicollenarity using the VIF test.

\begin{tabular}{cc}
\hline Variable & VIF \\
\hline $\operatorname{lnINT}$ & 1.44 \\
$\operatorname{lnEL}$ & 1.43 \\
RE & 1.39 \\
sqrtERN & 1.31 \\
\hline Mean VIF & 1.39 \\
\hline
\end{tabular}

Table 4 shows that the model meets such requirements as a high adjusted R2, a low level of root-mean-square error, and the probability of the coefficients being equal to zero for regressors is reduced to a minimum (at 5\% error probability). Additionally, when considering the repeated multicollinearity test (Table 5), the authors found that the selected variables were independent of each other. Figure 2 shows that all indicators are distributed linearly. In order to confirm that the model is of high quality, the authors perform the Ramsey test, which helps to determine whether there are any missing variables in the model. Based on the result of the Ramsey test, the authors are convinced that they could accept the null hypothesis that the model has no missing variables. Further, based on the link test, the authors confirm the hypothesis that the specification is defined correctly. 

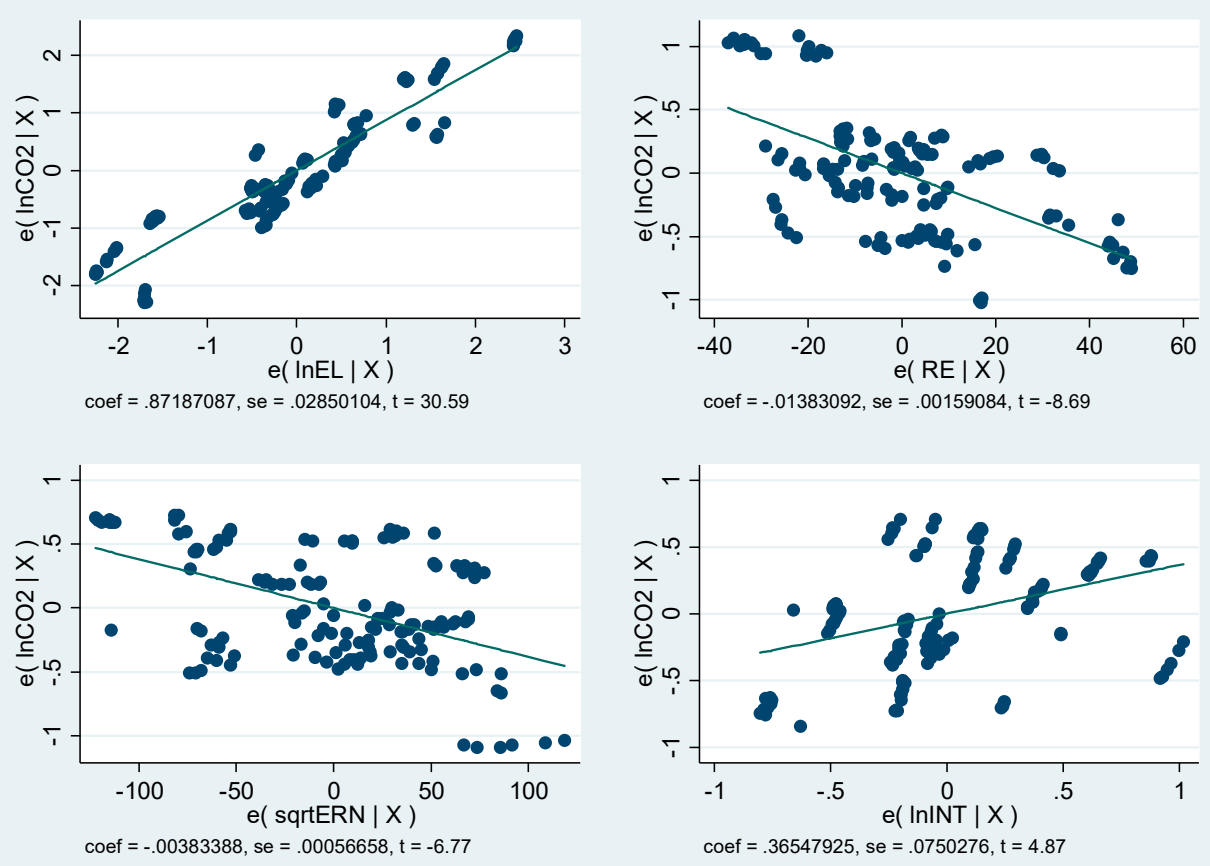

Figure 2. Test of the linearity of the relationship between the dependent and independent variables in the selected model.

In the process of further regression analysis, the authors checked the model for outliers. The appearance of outliers is associated with the influence of rare and/or usually ignored factors on the trait, as well as errors at the stage of measuring the trait. The outlier does not belong to the general population, so it is very important to exclude it from the analysis. There are quite a lot of methods for testing models for the content of emissions in them. According to the results of the DFBETA test, the authors detect no deviations from the standard values. Graphical testing using the lvr2plot command also allows the authors to establish that there are no obvious outliers.

According to the results of the White test, the residues are to a certain extent heteroscedostic, since the authors reject the null hypothesis about the uniformity of the residues. The second test, the Broich-Pogan test, shows, on the contrary, that the residues are homogeneous. Due to the ambiguity of the results of the two tests because of different approaches to assessing the heteroscedasticity of the residues, the authors perform the third test, the Goldfeld-Quandt test. The method of this test involves dividing the residues into two equal groups, and as a null hypothesis, the authors assume that the ratio of the groups of residues is exactly 1 (i.e., they are distributed uniformly). As a result of the test, the authors accept H0. Thus, two of the three tests confirm the uniformity of the distribution of residues. To confirm the results of testing for the normality of the remainder distribution, the authors present a graph of the remainder distribution in Figure 3.

Despite the fact that there are areas of deviation (in which the tests could show different results), the residuals are mostly distributed normally.

Now the authors perform the Shapiro-Wilk test, which can be used to confirm or disprove the null hypothesis that the residuals are distributed normally (Figure 4). Because of the test, the authors conclude that they cannot refute the null hypothesis that the residuals are distributed normally at the level of $5 \%$ significance. 


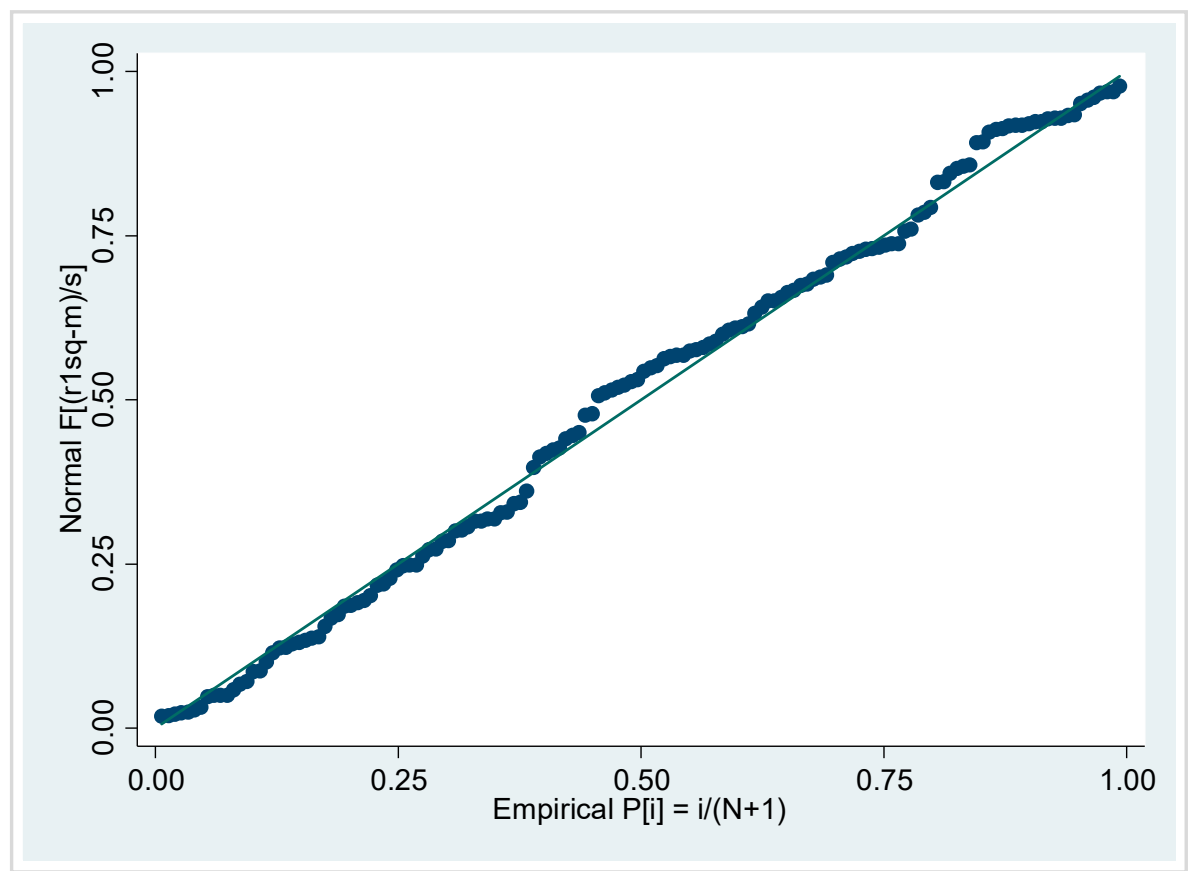

Figure 3. Normality of the residual distribution.

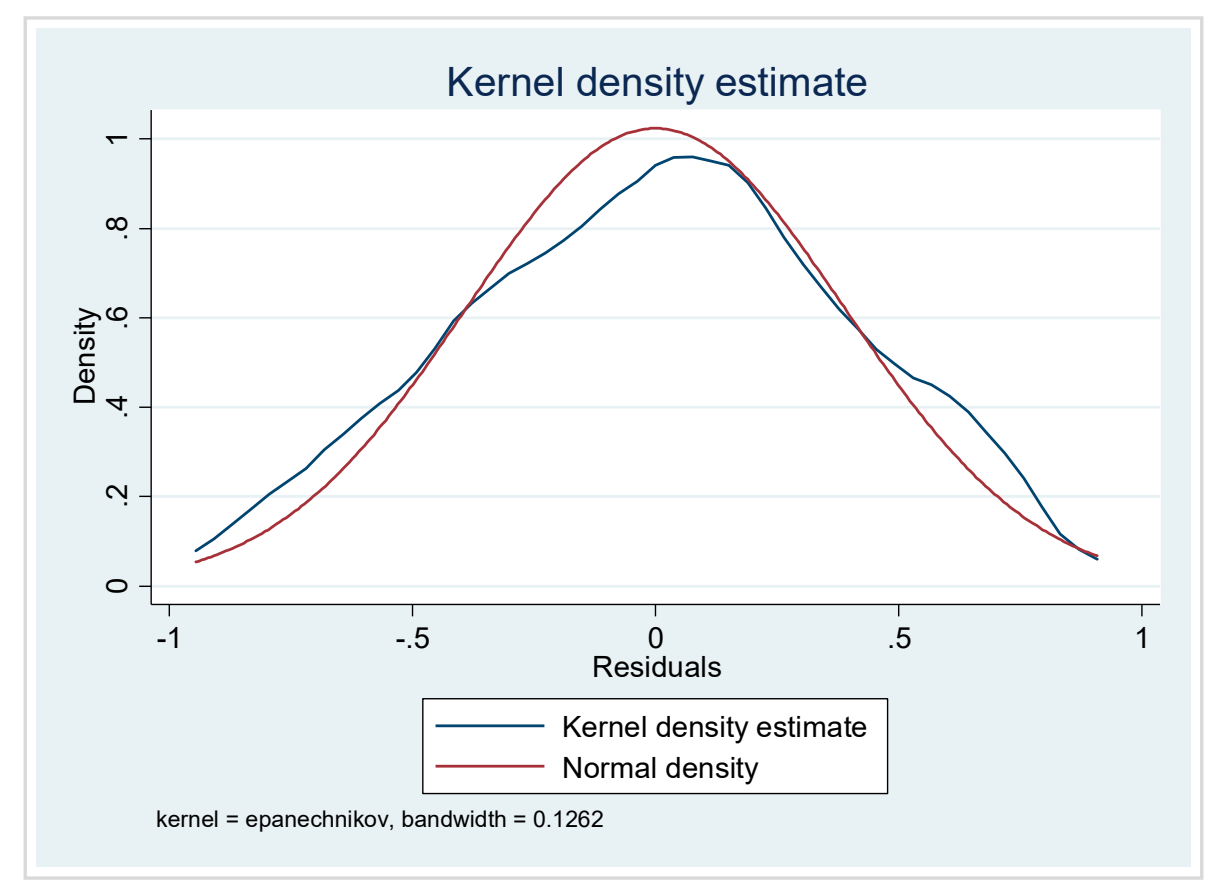

Figure 4. Estimation of the density of normally distributed random numbers.

Figure 4 shows that the density of the distribution is slightly different from the normal one, which is explained by the previous tests and the influence of the factors mentioned earlier. However, it is worth noting that the normal distribution form is present. If the authors compare the results of the tests, they can sum up: under these conditions, the balances are distributed relatively normally. 


\section{Results}

Thus, according to the regression table, it is obvious that all the coefficients for the indicators are significant, since the $p$-level value for the factors is less than 0.05 . The coefficient of determination R2 is at a high level, which indicates that the model has sufficient explanatory power. The value of the Fisher criterion is high, so the authors can conclude that the model is statistically significant. At the same time, it follows from the tests that the residuals are homoscedastic and all the variables selected as regressors are independent of each other.

The authors use an econometric analysis to obtain a model of the dependence of the resulting variable on the factor variables (OLS). The function of a simple linear regression model takes the following form (formula (2)):

$$
\mathrm{LnCO}_{2}=0.87 \times \operatorname{lnEL}-0.14 \times \mathrm{RE}-0.004 \times \mathrm{sqrtERN}+0.37 \times \operatorname{lnINT}+\mathrm{v}
$$

where $\mathrm{v}$ is a random error.

To determine the final form of the regression model, the authors also construct models with fixed and random effects during the analysis. Using the Wald, Broich-Pagan, and Hausman tests, the authors compare the three types of models with each other. The results show that the linear regression on the combined data is the most qualitative model for this study.

Thus, thanks to the analysis, the authors identify the most significant factor variables that can influence the level (amount) of $\mathrm{CO}_{2}$ emission. The EL factor, which means the amount of electricity consumed, has a direct relationship with the amount of $\mathrm{CO}_{2}$ emissions. Indeed, energy production is accompanied by high levels of emissions, and the more it is produced with ever-increasing demand, the more polluted the environment becomes. This is what the authors' model describes. As for the RE factor; on the contrary, it has an inverse relationship with the resulting indicator. The more a country includes RES in its energy mix, the more it reduces its annual $\mathrm{CO}_{2}$ emissions. That is why some countries (for example, Norway and Sweden) have tried to switch to RES as much as possible, as they are aiming to reduce harmful emissions into the atmosphere. We show the relationship between model indicators and SDG in the Figure 5.

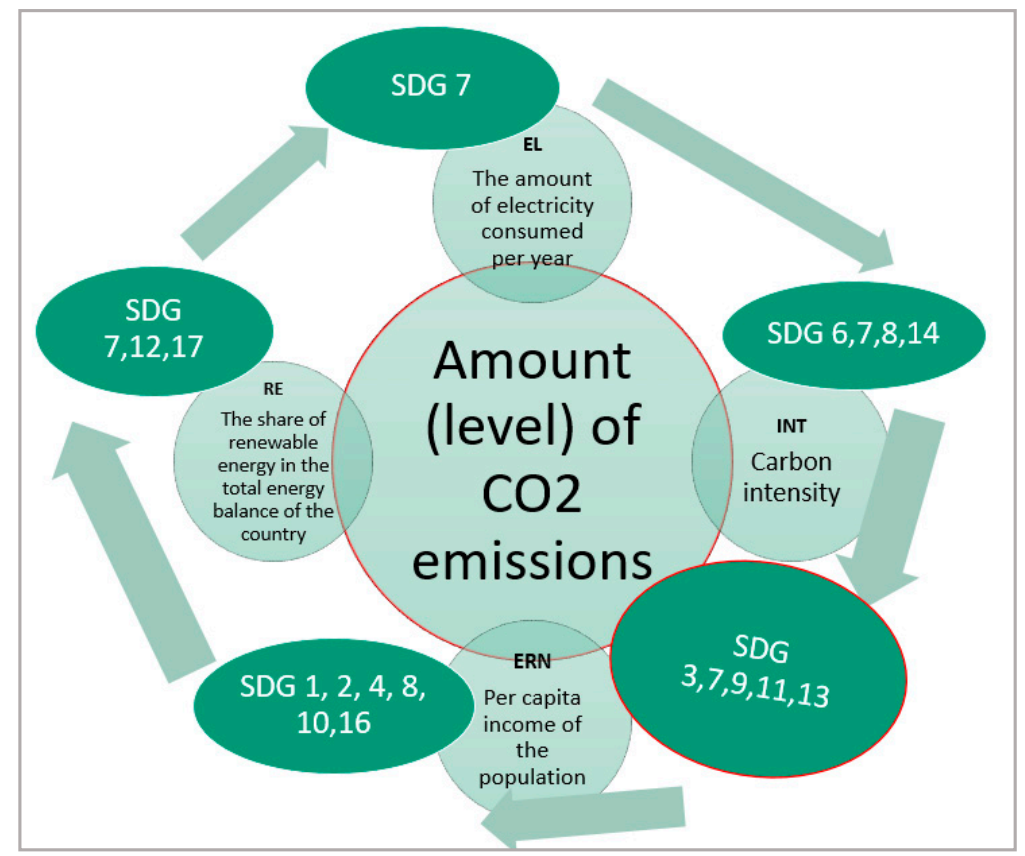

Figure 5. Relationship between the outcome model indicators and the Sustainable Development Goals. 
Each factor in the final model is associated with different goals, but together they are aimed at achieving a common global goal of sustainable development.

As the result of the conducted research, it is possible to accept the hypothesis that increasing the share of renewable sources in the energy balance of the country helps to make progress towards achieving the Sustainable Development Goals through the reduction the amount of harmful emissions into the atmosphere. It makes RES the recommended way to provide energy to remote territories, and, in particular, the Arctic zone of the Russian Federation. Due to the great remoteness of settlements, as well as the critical state of the environment in these areas, microgeneration based on RES comes to the fore as a source of affordable and clean energy. As a further direction of research, it is necessary to identify the key consumers of the Arctic zone, as well as to create a roadmap that would be a strategy for the development of renewable energy in the Arctic.

\section{Discussion}

Since this model was built on the basis of data on countries that adhere to decarbonization policies, this fact can be considered a limitation of the model. However, since all countries that have Arctic territories in their composition adhere to this policy, this does not affect the results of the study and conclusions.

The researchers also confirm the conclusions obtained in this work. For example, V. N. Leksin et al. point out that it would be possible to ensure the energy and economic security of the territories by increasing energy efficiency and developing renewable energy sources in the Russian Arctic [46]. The authors Kirsanova N. Y et al. also confirm that the use of renewable energy sources in the conditions of decentralized power supply in the Arctic is necessary [47].

Although the relationship between the use of renewable sources and $\mathrm{CO}_{2}$ emissions has been studied previously, the authors used different approaches. For example, the authors Jebli M. B. et al. [48] and Dong K. et al. [49] collected a panel of data by income level and investigated the effect of RES on $\mathrm{CO}_{2}$ emissions depending on the income level of countries, not on the decarbonization policy and SDG. Khattak S. I. et al. [50] investigated $\mathrm{CO}_{2} \mathrm{e}$. Renewable energy was found to have a disrupting impact on $\mathrm{CO}_{2} \mathrm{e}$ in BRICS, Russia, India, and China, excluding South Africa. Authors de Souza Mendonça A. K. et al. investigated the impact of renewable energy, GDP, and population on $\mathrm{CO} 2$ emissions [51]. Results showed that renewable energies can be effective substitutes for other fossil fuels, such as coal and oil, in the pursuit of reducing $\mathrm{CO}_{2}$ emissions. In addition, in many studies, RES is indicated as a recommendation for reducing $\mathrm{CO}_{2}$, but authors do not investigate it as a factor $[52,53]$.

A possible further direction of the study is the cluster analysis of the Arctic territories by climatic characteristics. This is necessary to study the climatic conditions of each zone and select the most efficient source of generation.

In addition, the issue of further disposal of parts of renewable energy installations remains unresolved. Despite the fact that the assessment of the environmental impact of the life cycle of the fastest growing types of renewable energy sources is a popular topic in the scientific literature, it is still insufficiently studied [54].

\section{Conclusions}

RES have a huge potential for use in the Russian Federation, and the Arctic zone is no exception. Having significant reserves of renewable resources, the transition to the use of renewable energy is simply necessary in this territory.

In this paper, the authors consider RES in the context of sustainable development and solving the global problem of climate change, according to the Sustainable Development Goals. The authors conclude that every year countries increase the share of renewable sources in their energy balance and choose different directions for their use. The growth in the use of RES is primarily due to the desire of countries to reduce the amount of harmful emissions into the atmosphere. Increasing the share of renewable energy in the energy 
balance, as well as reducing the level of emissions, are spelled out in the development strategies of the EU countries, China, etc. Thanks to the increased use of renewable sources, many countries have already achieved a reduction in annual $\mathrm{CO}_{2}$ emissions.

As a result of an extensive literature review, it was possible to consider various points of researchers view on the use of renewable energy sources. In this regard, we can conclude that RES is not only a source of electricity, but also a part of the infrastructure and sustainable development of the Arctic region. In addition, RES can be used for combined electrical installations, as well as for heat generation.

Econometric modeling confirms the hypothesis of the relationship between the use of renewable energy sources and the achievement of progress on the Sustainable Development Goals, one of the indicators of which is the level of $\mathrm{CO}_{2}$ emissions. In the final model, the following variables remain: the level of $\mathrm{CO}_{2}$ emissions, the amount of electricity consumed per year, the share of renewable energy in the total energy balance of the country, carbon intensity $\left(\mathrm{CO}_{2}\right.$ emissions per GDP), and the average per capita income of the population. By influencing these factors, it is possible to influence the reduction of $\mathrm{CO}_{2}$ emissions to achieve the Sustainable Development Goals.

When analyzing the regulatory and legal regulation in the field of renewable energy in different countries, as well as describing the existing measures of state support for the industry, the authors reveal that there is a lack of an effective regulatory framework, as well as incentive support measures, to increase the use of renewable energy in Russia, especially in remote areas (the Arctic zone). Currently, these measures are being actively discussed, but no active actions have been taken.

With the existing prospects, as well as within the framework of the Sustainable Development Goals, it is necessary to support this industry and stimulate it for development, according to the Sustainable Development Goals.

Author Contributions: Conceptualization, V.B., S.G. and A.Z.; methodology, A.Z.; validation, V.B., and S.G.; formal analysis, V.B.; investigation, V.B., S.G. and A.Z.; writing-original draft preparation, V.B. and S.G.; writing-Review and editing, V.B. and S.G.; visualization, V.B.; project administration, S.G.; funding acquisition, A.Z. All authors have read and agreed to the published version of the manuscript.

Funding: This research received no external funding.

Institutional Review Board Statement: Not applicable.

Informed Consent Statement: Not applicable.

Conflicts of Interest: The authors declare no conflict of interest.

\section{References}

1. Erickson, L.E. Reducing greenhouse gas emissions and improving air quality: Two global challenges. Environ. Prog. Sustain. Energy 2017, 36, 982-988. [CrossRef]

2. Guarino, M.-V.; Sime, L.C.; Schröeder, D.; Malmierca-Vallet, I.; Rosenblum, E.; Ringer, M.; Ridley, J.; Feltham, D.; Bitz, C.; Steig, E.J.; et al. Sea-ice-free Arctic during the Last Interglacial supports fast future loss. Nat. Clim. Chang. 2020, 10, 928-932. [CrossRef]

3. Kattsov, V.M.; Porfiriev, B.N. Climate change and its impact on the environment and economy of the Russian Arctic. Arct. Ecol. Econ. 2012, 2, 7-26.

4. Konovalov, A.M. Transport infrastructure of the Russian Arctic: Problems and ways to solve them. Arctic: A Zone of Peace and Cooperation; Institute of World Economy and International Relations of the Russian Academy of Sciences: Moscow, Russia, 2011; pp. 120-141.

5. Tzimas, E.; Georgakaki, A.; Peteves, S. Reducing $\mathrm{CO}_{2}$ emissions from the European power generation sector-Scenarios to 2050 . Energy Procedia 2009, 1, 4007-4013. [CrossRef]

6. Sokolov, Y.I. The Arctic: On the Problem of Accumulated Environmental Damage. The Barents Sea. Available online: http: //barenzevo.arktikfish.com/index.php/ekologiya-barentseva-morya/703-arktika-k-probleme-nakop (accessed on 27 October 2020).

7. Inozemtsev, V. Time to Collect Barrels. Available online: http://russiancouncil.ru/inner/?id_4=795\#top-content (accessed on 27 October 2020).

8. Gabderakhmanova, T.S.; Kiseleva, S.V.; Popel, O.S.; Tarasenko, A.B. Some aspects of the development of renewable energy in the Arctic zone of the Russian Federation. Altern. Energy Ecol. 2016, 41-53. [CrossRef] 
9. Morgunova, M.O.; Solovyov, D.A. Energy Supply of the Russian Arctic: Hydrocarbons or RES? System Consulting LLC: Moscow, Russia, 2016; p. 14.

10. Smolentsev, D.O. Arctic energy Development: Challenges and opportunities for small-scale generation. Arct. Ecol. Econ. 2012, 3, 22-29.

11. Strategy for the development of the Arctic zone of the Russian Federation and ensuring national security for the period up to 2020. The Edict of the President of the Russian Federation of 18 September 2008. Moscow. 2008. Available online: https://www.garant.ru/products/ipo/prime/doc/74710556/ (accessed on 27 October 2020).

12. Popel, O.S. The use of renewable energy sources for energy supply to consumers in the Arctic zone. Arct. Ecol. Econ. 2015, 1, 64-69.

13. Adhikari, G.C.; Vargas, P.A.; Zhu, H.; Grigoriev, A.; Zhu, P. Tetradic phos-phor white light with variable CCT and superlative CRI through organolead halide perovskite nanocrystals. Nanoscale Adv. 2019, 1, 1791-1798. [CrossRef]

14. Adhikari, G.C.; Thapa, S.; Zhu, H.; Zhu, P. Mg2+-Alloyed All-Inorganic Halide Perovskites for White Light-Emitting Diodes by 3D-Printing Method. Adv. Opt. Mater. 2019, 7, 1900916. [CrossRef]

15. Adhikari, G.C.; Thapa, S.; Zhu, H.; Grigoriev, A.; Zhu, P. Synthesis of CsPbBr3 and transformation into Cs4PbBr6 crystals for white light emission with high CRI and tunable CCT. J. Phys. Chem. C 2019, 123, 12023-12028. [CrossRef]

16. Bushuev, V.V.; Zaichenko, V.M.; Morgunova, M.O.; Chernyavsky, A.A.; Solovyov, D.A. The potential of RES in the Arctic: New challenges. Materials of the International Conference "Revived Energy: Problems and Prospects" and the X School of Young Scientists "Actual problems of the development of revived energy resources" named after corresponding members of the RAS E. E. Shpilraina. 2017, Volume 1, pp. 94-99. Available online: https://istina.msu.ru/conferences/86891779/ (accessed on 28 October 2020).

17. Kireeva, A. Three Remote Villages of the Murmansk Region Will Be Powered by “Green” Energy-Bellona.ru. Available online: http:/ / bellona.ru/2014/10/08/triudalennyh-poselka-murmanskoj-obl/ (accessed on 27 October 2020).

18. Sharovarova, E.P.; Alyokhin, V.N. Potential of RES development in the territories of Russia with decentralized energy supply. SUC 2020, 5, 54-55.

19. Ignatieva, V.; Gadal, S. Alternative energy sources as a component of sustainable development of the Arctic regions. In Arctic Regions of Russia: The Role of National Projects in Shaping Sustainable Development; National School of Public and Business Administration: Moscow, Russia, 2020; pp. 732-743.

20. Bezrukikh, P.P. (Ed.) Wind Energy: Reference and Methodological Manual; Publishing house «Energy»: Moscow, Russia, 2010; 313p.

21. Aliukov, S.A.; Shishkov, A.A.; Ma, J.B.; Li, M.B.; Wang, S. Economic Cluster Analisis and Fuzzy Modelling of Operation of Wind Power Plants in the Arctic. IOP Conf. Ser. Earth Environ. Sci. 2020, 459, 062064. [CrossRef]

22. Guliyev, I.A.; Ruzakova, V.I. Prospects for the Development of Renewable Energy in the Arctic Zone of the Russian Federation, Taking into Account International Experience. Ecological Bulletin of Russia. Available online: http: / / ecovestnik.ru/index.php/2013-07-07-02-13-50/nashi-publikacii/2904-perspektivy-razvitiya-vie-v-arkticheskoj-zonerossijskoj-federatsii-s-uchetom-mezhdunarodnogo-opyta (accessed on 27 October 2020).

23. Nazarova, Y.A.; Syrovetsky, V.A. The Possibilities of Using Renewable Energy Sources for the Energy Supply of the Arctic. Available online: http:/ /vestnik-ku.ru/ru/arkhiv/2018-rus/vestnik-4-2018-rus/43-2018-rus/349-vozmozhnosti-ispolzovaniyavozobnovlyaemykh-istochnikov-energii-dlya-energoobespecheniya-arktiki (accessed on 27 October 2020).

24. Potravny, I.M.; Yashalova, N.N.; Boroukhin, D.S.; Tolstoukhova, M.P. The use of renewable energy sources in the Arctic: The role of public-private partnership. Econ. Soc. Chang. Facts Trends 2020, 13, 144-159.

25. Quitoras, M.R.; Campana, P.E.; Crawford, C. Exploring electricity generation alternatives for Canadian Arctic communities using a multi-objective genetic algorithm approach. Energy Convers. Manag. 2020, 210, 112471. [CrossRef]

26. Giordano, N.; Raymond, J. Alternative and sustainable heat production for drinking water needs in a subarctic climate (Nunavik, Canada): Borehole thermal energy storage to reduce fossil fuel dependency in off-grid communities. Appl. Energy 2019, 252, 113463. [CrossRef]

27. Das, I.; Cañizares, C.A. Renewable energy integration in diesel-based microgrids at the Canadian arctic. Proc. IEEE 2019, 107, 1838-1856. [CrossRef]

28. Christakos, K.; Varlas, G.; Cheliotis, I.; Spyrou, C.; Aarnes, O.J.; Furevik, B.R. Characterization of wind-sea-and swell-induced wave energy along the Norwegian Coast. Atmosphere 2020, 11, 166. [CrossRef]

29. Chesnokova, S.V. China remains a leader in the development of renewable energy. East. Anal. 2012, 3, 161-164.

30. Batova, T.; Lazareva, E.; Pavlova, E. Sustainable use of natural resources in the Arctic region (the example of China's cooperation with Western countries). E3S Web Conf. 2019, 110, 02064. [CrossRef]

31. Jung, W.; Jeong, J.; Chang, D. Design of renewables-battery combined energy system for energy isolated island. In Proceedings of the 29th International Ocean and Polar Engineering Conference, Honolulu, HI, USA, 16-21 June 2019.

32. Sirviö, K.; Niemi, S.; Help, R.; Heikkilä, S.; Hiltunen, E. Behavior of B20 fuels in arctic conditions. Agron. Res. 2019, 17, 1207-1215.

33. Mathanlal, T.; Martin-Torres, J.; Bhardwaj, A.; Mier, M.-P.Z. Self-sustainable monitoring station for extreme environments (s3me2): Design and validation. In Proceedings of the 2nd International Conference on Green Computing and Internet of Things (ICGCIoT), Bangalore, India, 16-18 August 2018; pp. 240-245.

34. Dunichkin, I. Transport Interchange Hubs under the Conditions of the Far North. Advances in Intelligent Systems and Computing. In Energy Management of Municipal Transportation Facilities and Transport; Springer: Cham, Switzerland, 2017 ; pp. 446-452. 
35. Zhakisheva, A.A. Ways to prevent the harmful impact of oil and gas production on the environment. Bull. Chelyabinsk State Univ. 2011, 32, 142-149.

36. Framework Convention on Climate Change. Available online: https://unfccc.int/resource/docs/2015/cop21/rus/109r.pdf (accessed on 17 November 2020).

37. General Characteristics of Anthropogenic Impacts on the Natural Environment. Ecology: Work and Life. Available online: https:/ / ekdel.ru/problemy/antropogennoe-eto.html (accessed on 20 December 2020).

38. Le Quéré, C.; Korsbakken, J.I.; Wilson, C.; Tosun, J.; Andrew, R.; Andres, R.J.; Canadell, J.G.; Jordan, A.; Peters, G.P.; van Vuuren, D.P. Drivers of declining $\mathrm{CO}_{2}$ emissions in 18 developed economies. Nat. Clim. Chang. 2019, 9, 213. [CrossRef]

39. Tishkov, S.; Shcherbak, A.; Karginova-Gubinova, V.; Volkov, A.; Tleppayev, A.; Pakhomova, A. Assessment the role of renewable energy in socio-economic development of rural and Arctic regions. Entrep. Sustain. Issues 2020, 7, 3354-3368. [CrossRef]

40. Marin, G.; Mazzanti, M. The evolution of environmental and labor productivity dynamics. J. Evol. Econ. 2013, 23, 357-399. [CrossRef]

41. Kudryavtseva, O.; Ivanov, E.; Kolesnik, D.; Matveev, E.; Pechenkin, S. Assessment of the impact of the level of environmental pollution on economic growth. Sci. Res. Fac. Econ. Electron. J. 2017, 9, 68-80.

42. Zaytsev, A.; Konnikov, E.; Asaturova, Y.; Didenko, S. Modelling the cyclic influence of climate change on the world economic system. In Proceedings of the 1st International Symposium of Earth, Energy, Environmental Science and Sustainable Development, JESSD, Jakarta, Indonesia, 28-30 September 2020; Volume 211. [CrossRef]

43. Poumanyvon, P.; Kaneko, S. Does Urbanization Lead to Less Energy Use and Lower $\mathrm{CO}_{2}$ Emissions? A Cross-Country Analysis. Ecol. Econ. 2010, 70, 434-444. [CrossRef]

44. Halkos, G.E.; Paizanos, E.A. The effect of government expenditure on the environment: An empirical investigation. Ecol. Econ. 2013, 91, 48-56. [CrossRef]

45. Li, L.; Lei, Y.; He, C.; Wu, S.; Chen, J. Prediction on the Peak of the $\mathrm{CO}_{2}$ Emissions in China Using the STIRPAT Model. Adv. Meteorol. 2016, 2016, 5213623. [CrossRef]

46. Leksin, V.N.; Porfiriev, B.N. Socio-economic priorities of sustainable development of the Arctic macroregion of Russia. Econ. Reg. 2017, 13, 985-1004.

47. Kirsanova, N.; Lenkovets, O.; Nikulina, A. Renewable energy sources (RES) as a factor determining the social and economic development of the arctic zone of the Russian Federation. Int. Multidiscip. Sci. GeoConf. SGEM 2018, 18, 679-686.

48. Jebli, M.B.; Farhani, S.; Guesmi, K. Renewable energy, $\mathrm{CO}_{2}$ emissions and value added: Empirical evidence from countries with different income levels. Struct. Chang. Econ. Dyn. 2020, 53, 402-410. [CrossRef]

49. Dong, K.; Dong, X.; Jiang, Q. How renewable energy consumption lower global $\mathrm{CO}_{2}$ emissions? Evidence from countries with different income levels. World Econ. 2020, 3, 1665-1698. [CrossRef]

50. Khattak, S.I.; Ahmad, M.; Khan, Z.U.; Khan, A. Exploring the impact of innovation, renewable energy consumption, and income on CO2 emissions: New evidence from the BRICS economies. Environ. Sci. Pollut. Res. 2020, 27, 13866-13881. [CrossRef] [PubMed]

51. de Souza Mendonça, A.K.; Barni, G.D.A.C.; Moro, M.F.; Bornia, A.C.; Kupek, E.; Fernandes, L. Hierarchical modeling of the 50 largest economies to verify the impact of GDP, population and renewable energy generation in $\mathrm{CO}_{2}$ emissions. Sustain. Prod. Consum. 2020, 22, 58-67. [CrossRef]

52. Yao, C.; Feng, K.; Hubacek, K. Driving forces of $\mathrm{CO}_{2}$ emissions in the G20 countries: An index decomposition analysis from 1971 to 2010. Ecol. Inform. 2015, 26, 93-100. [CrossRef]

53. Deutch, J. Decoupling economic growth and carbon emissions. Joule 2017, 1, 3-5. [CrossRef]

54. Ratner, S.; Gomonov, K.; Revinova, S.; Lazanyk, I. Eco-Design of Energy Production Systems: The Problem of Renewable Energy Capacity Recycling. Appl. Sci. 2020, 10, 4339. [CrossRef] 